\title{
Exploring the Organizational Benefits and Implementation Challenges of Preparing an Integrated Report in Mauritius
}

\author{
https://doi.org/10.21272/fmir.2(4).101-109.2018
}

\section{Tishta Bachoo}

Lecturer in Accounting, School of Accounting, Curtin University, Mauritius

Nassr Saleh Mohamad Ahmad

Professor, Accounting Faculty, University of Gharyan, Gharyan- Libya, General Manager of Human Resources Development Institute, Libyan Academy, Tripoli-Libya, Libya

\begin{abstract}
Preface: Integrated Reporting (IR) is a new concept which has been receiving considerable attention from the global community since the formation of the International Integrated Reporting Council (IIRC) in 2010. Mauritius is a fast-developing country where IR has gained growing traction over the last three years. It is important to understand the potential for IR in this island where sustainable development must be central to economic thinking as the island state has to preserve its resources in the long run.

Purpose: This paper aims to find out the organizational benefits and implementation challenges of preparing an Integrated Report in Mauritius.

Methodology: A survey is carried out to extract responses from report preparers and other stakeholders (investors, analyst and auditors) from a wide range of industries in Mauritius.

Findings: IR is being adopted by a majority of companies in Mauritius, although it is a relatively new concept. a majority thinks IR is improving the current corporate reporting. However, the fear of divulging market and/ or price sensitive information was the main challenge facing the practices of IR in Mauritius.

Contribution: The study explores the opinions of various stakeholders regarding IR which have not been taken in Mauritius. The findings may be useful to better understand the likely development of IR in developing markets, as most of the previous studies on IR focused on developed countries and South Africa.
\end{abstract}

Keywords: Accounting, International Integrated Reporting Council, Integrated Reporting, Technology, Mauritius.

JEL Classification: O10, M4.

Type of Paper: Empirical Study.

Cite as: T. Bachoo, N. S. M. Ahmad. (2018). Exploring the Organizational Benefits and Implementation Challenges of Preparing an Integrated Report in Mauritius, Financial Markets, Institutions and Risks, 2(4), 101-109. https://doi.org/10.21272/fmir.2(4).101-109.2018

(C) The Authors, 2018. This article is published with open access at Sumy State University.

\section{Introduction}

The environment in which accountants work is rapidly changing due to the emergence of information technology and the globalization of economies (Tan \& Laswad, 2018). For years, businesses have been held back by markets focused on the short-term, a lack of long term thinking and a shortage of information on the true sources of reliable value creation in a company over time - things like innovation, brand equity, customer loyalty, and key stakeholder relationships (IR Technology Initiative, 2016). Fortunately, there is a tool to help businesses understand, manage and communicate about the sources of value creation: IR.

As described by the IIRC, IR is an evolution of corporate reporting, emphasizing on conciseness, strategic relevance and future orientation (IIRC, 2013). IR is gaining momentum globally and it has the potential to bring about transformational changes in the roles of accounting professionals and in the standing of the profession itself. This sort of next-generation approach to business thinking, management and reporting depends on broader information sets and quicker, more sophisticated ways of analyzing the material information required for decision-making (IR Technology Initiative, 2016). 
IR has evolved rapidly since the International Integrated Reporting Council (IIRC) was founded in 2010 (Hopwood, Unerman \& Fries, 2010). In 2015, the IIRC's then CEO, Paul Druckman, used a journey metaphor to explain developments in IR practice: "IR is a journey and it will take more than one reporting cycle to get there. As businesses start to use IR as a tool to better understand the connections between key resources and relationships that contribute to their success, and as a result make more informed decisions, the real value of integrated thinking and the integrated report will be realized" (IIRC, 2015).

While the accounting role was restricted to the provision of financial information and analysis, in the current climate, more and more investors demand non-financial data when screening a company. Therefore, businesses are expected to report not just on profit but on their impact on the wider economy, society, and the environment. In this context, IR comes handy as it gives a 'dashboard' of an organization's activities and performance in this broader information flow. In modern companies, it requires the application of technology to the transition from the current model of management practice and corporate reporting (largely financial only) to an integrated view.

However, prior studies on integrated reporting in the African context are rare except for South Africa where a number of empirical studies exist (Ahmed Haji and Anifowose, 2016; Steyn, 2014; Atkins and Maroun, 2015; Setia, Abhayawansa, Joshi, \& Huynh, 2015; Ahmed Haji and Anifowose, 2017; Ahmed Haji and Hossain, 2016, McNally, Cerbone, \& Maroun 2017). Little in other African countries such as Islam and Islam (2018) (Bangladesh) and Lipunga (2015) (Malawi). The mainstream of empirical studies have utilized evidence from UK, US, Europe and Asia. Internationally, there is still limited research on IR (Adhariani and de Villiers, 2018; Lodhia, 2015; Haller and Van Staden, 2014; Robertson and Samy, 2015; Atkins, Solomon, Norton \& Joseph, 2015). Thus, this study fills the gap in literature by exploring the organizational benefits and implementation challenges of preparing an IR in Mauritius as an African country. It is mainly trying to answer the following questions: RQ1: To what extent companies in Mauritius are adopting IR? RQ2: What are the perceived benefits and challenges for report preparers?

To achieve its aims, the paper proceeds as follows: Section 2 provides an overview of IR's literature. Section 3 explains the methods used to capture data for further analysis. Section 4 presents results and is dedicated to a discussion of the findings. The final section draws conclusions and sketched an agenda for future research.

\section{Literature Review}

Prior to the adoption of IR, stakeholders were either interested in financial data or in Environmental, Social and Governance (ESG) data, but rarely both. The company's integrated report attempts to show the interdependency of non-financial and financial performance (Eccles and Saltzman, 2011). Moreover, there is now a growing adoption of already established frameworks and guidelines that serve to assist companies in their journey towards issuing the integrated report (Petrova, 2015). Some of these include the International Integrated Reporting Framework and the Global Reporting Initiative (GRI) - allegedly the most widely adopted guidelines on reporting non-financial information (GRI, 2018).

The International Integrated Reporting Council (IIRC) (2013) defines IR as "a process founded on integrated thinking that results in a periodic integrated report by an organization about value creation over time and related communications regarding aspects of value creation". Therefore, preparing a single integrated report, also referred to as 'One Report', eliminates the ambiguity of disclosing both financial and non-financial information in a clear and concise manner (Owen, 2013; Eccles, 2010). IR adds value to a company by highlighting how green and ethical values drive long-term growth (Nylander, 2015).

Mr. Richard Howitt, current CEO of IIRC stated in his interview on 22 May 2017 that, over 1,500 global businesses from big companies like PepsiCo and Unilever to major banks like Deutsche Bank and big major pharmaceutical companies as well as insurance companies, have adopted IR principles for various reasons (EY, 2017). While some have adopted IR because of legislative pressure (for example in South Africa and Brazil where IR is mandatory by law), others have understood the benefits derived from it, in the form of reputation, effective decisions and capital allocation, profit increases on short and long-term, future orientation, stakeholder agreement, retaining customers and employees (Roman, 2017). Research provides evidence of momentum towards IR in other countries, including the United Kingdom, the Netherlands, Australia, Spain, Singapore, Japan and the United States of America. Whether applied on a voluntary basis or not, IR practices provide many advantages such as reputation, a better understanding of the impact of the business on the environment or society or correlating financial and non-financial performances (Bhasin, 
2017). However, Islam and Islam (2018) sated that companies in Bangladesh still lack in providing an integrated report connecting financial and non-financial information.

Adoption of IR results in several improvements that are indirectly linked to performance, like relations with external stakeholders, improvement in decision making and management of information, improving what is measured and connecting departments. According to Reimsbach, Hahn and Gürtürk (2017), an integrated report might influence the valuation of a company and in the end, attract more investors. However, the implementation of IR is not without its challenges. There will be need for the co-ordination of inter-functional activities (Eccles \& Saltzman, 2011)) because an integrated report calls for the synchronization of financial and non-financial information to be elicited across various departments in an organization. Technology plays an important role in IR adoption. Software would have to be acquired to fuse financial and non-financial data. Information Technology hardware may also have to be procured to capture relevant tangible and non-tangible data. Investment would have to be made to train human assets of organizations on IR. Since the IR framework is still evolving, organizations will have to decide on the appropriate level of details to disclose. At the heart of these barriers to implementation is cost. The acquisition of computer equipment, training of staffs, and awareness creation all call for financial commitment.

Finally, Although a similar research has been conducted in developing countries such as Bangladesh (Islam and Islam, 2018), Malawi (Lipunga, 2015), and Indonesia (Adhariani and de Villiers, 2018), results cannot be expected to be the same in Mauritius due to significant contextual differences in terms of corporate reporting, the use of corporate information and the corporate culture.

\section{Methodology}

To answer the research questions developed in the previous section, a survey instrument is used targeting corporate report preparers and other stakeholders (investors, analyst and auditors). The survey which was adapted from the Malaysian Institute of Accountants (MIA) - ACCA (2016) and the Institute of Singapore Chartered Accountants (ISCA) - National University of Singapore (NUS) (2014) integrated reporting surveys, allowed numerous forms of questions to be asked and enabling proper feedback. The survey was directed in a specific way in order to invite and receive as many responses. In this research, both primary and secondary data were collected. As a result of a dearth of Mauritian studies relevant to IR, studies from foreign countries were used to meet the targeted objectives of this research. In this research, the population encompasses the accounting practitioners from a wide range of industries. The first target was the 13 companies which have won the SEM Sustainability Index (SEMSI) award (Stock Exchange of Mauritius [SEM], 2018). The reason these companies were chosen for this research is that they are already actively pursuing sustainability initiatives, while also facilitating responsible investment. However, due to a small population size, the data collection was extended to other listed companies and some multinational companies based in Mauritius, considering that these companies must have already adopted IR as this concept is no more new on the international level. The corporate report preparers were surveyed so as to get an idea of what they are doing in regards to the IR concept, and also how this new concept is changing their roles and that of their accounting staff members.

The total population sampling which is a type of purposive sampling technique that involves examining the entire population has been used (Etikan, Musa \& Alkassim, 2016). Due to the very small sample size and the uncommon characteristics of populations that make up a total population sample, the study looks at the samples in-depth using mixed research methods. To minimize non- response bias, the following steps were taken: (1) the participants were asked to complete the survey even if they had little or no interest in IR or if their companies have not implemented the concept; (2) online questionnaires were used to improve response rate and to allow the respondents to fill the surveys at their own time; and (3) the anonymity of the survey data was ensured.

Thus, out of the $\mathbf{1 0 0}$ companies which participated, $\mathbf{7 0}$ of them responded to the surveys. The respondents had to classify themselves into different groups based on the position they held:

(1) IR Preparer I: Audit Committee, Independent Directors and Board Members (4 coded as B01 to B04); (2) IR Preparer II: Chief Executive Officers; (3) IR Preparer III: Finance function including Chief Financial Officers, Financial Controllers and Accountants (39 and they were coded as P01 to P39); (4) IR Preparer IV: Corporate Communication, Sustainability Practitioner; (5) Auditors and Consultants (11 were consultants while 10 were auditors working in the companies, coded as C01 to C11 and A01 to A10, respectively); and (6) Other Stakeholders: Analysts and Shareholders (6 coded as S01 to S06). Unfortunately, no IR 
preparers II (Chief Executive Officers) and IV (Sustainability Practitioner) filled in the survey so their views could not be analyzed. However, from the types of respondents who filled in the survey, it can be deduced that they were all from the accountancy field which implies that they were the right candidates who have knowledge about IR.

To calculate the descriptive values of the data, the software SPSS 22.0 is used. In return, we shall know the opinions of the respondents on different aspects of IR. The questions found in a different section of the questionnaire is tested using frequency table, bar chart and pie charts in order to find out their perceptions. The last two questions from the survey are open-ended questions which will be analyzed qualitatively. Finally, it is worth to mention that the respondents were from a wide range of industry. However, the majority of them were accounting practitioners from the financial sector $(30 \%)$ and the second was the manufacturing sector $(17 \%)$.

\section{Results and Discussion}

\section{RQ1: To what extent companies in Mauritius are adopting IR?}

To answer the first research question (RQ1) about the extent to which companies in Mauritius are adopting IR, it was important to identify whether the respondents were aware of the new concept and whether it is impacting their roles. By using scale on 1 to 5, 1 being 'no knowledge' to 5 being 'high knowledge' the participants were asked how much they know about IR and were asked to rate their awareness. Out of the 70 respondents, 11 and 22 of them gave a rating of 5 and 4 respectively (47\%) which are the top two knowledge categories, categorizing themselves as having higher than average level of knowledge in IR. $28(40 \%)$ of them gave a rating of 3 which was average knowledge. The remaining $9(13 \%)$ had little knowledge to no knowledge of IR. As it can be deduced, although IR is a relatively young initiative globally, and take-up by companies in Mauritius has so far been limited, these companies are not clueless about the concept. The majority of the respondents have more than just the basic notion of IR.

This leads to high level of adoption where 44 companies (63\%) have already adopted IR while $26(27 \%)$ are considering to adopt it in the near future. It can be deduced that none of the respondents answered 'No' which implies that they are positive about the adoption of IR. The largest group overall (44\%) think IR should be required on an 'apply or explain' basis, whereas $29 \%$ think should simply be made mandatory. Just under a third $(27 \%)$ of respondents think the introduction of IR in Mauritius should be market driven. Whatever the implementation approach, some participants think that the concepts underlying IR will be equally applicable to small and medium-sized enterprises (SMEs), the public sector and not-for-profit organizations.

\section{RQ2: What are the perceived benefits and challenges for report preparers?}

The report preparers have mentioned that IR in their companies is beneficial to their roles and that of their subordinates. Of this group, a majority ( 55 out of 70 respondents) thinks IR is improving the current corporate reporting. 15 of them answered "maybe" which means they are not very sure. This is because these 15 have not yet implemented the concept. This group was also asked to identify perceived benefits from a list, selecting as many as they liked. The dominant benefits they perceive included improving transparency and governance, improving communication with external stakeholders and promoting integrated thinking, all of which were in line with the MIA-ACCA (2016) survey. This finding is consistent with previous studies (Deegan and Rankin, 1997; and García-Sánchez, Rodríguez-Ariza and Frías-Aceituno, 2013). Of lesser importance were the benefits related to easier access to capital, increased share price and improving efficiency. The findings suggest that the information provided in IR may be of little use for capital market participants, which is consistent with the findings of Rensburg and Botha (2014) in South Africa, and Hsiao and Kelly (2017) in Taiwan.

A regression analysis was then conducted in order to verify the relationship between the dependent variable and the independent variables. The dependent variable is the adoption of IR and the independent variables are those which influence its adoption, such as awareness of the concept, the cost for implementation, how beneficial it is to the roles of accountants, how relevant and significant it is to the accounting profession and lastly the value IR adds to the organization and shareholders. A multiple linear regression test was chosen to analyze the relationship between the dependent variable and independent variables in the sample. The rest showed the following results. 
Table 1. Regression model summary

\begin{tabular}{|c|c|c|c|c|c|c|c|c|c|}
\hline & & & \multirow{2}{*}{} & \multirow{5}{|c|}{ Change Statistics } \\
\cline { 5 - 10 } Model & $\mathrm{R}$ & R Square & $\begin{array}{c}\text { Adjusted R } \\
\text { Square }\end{array}$ & $\begin{array}{c}\text { Std. Error of } \\
\text { the Estimate }\end{array}$ & $\begin{array}{c}\text { R Square } \\
\text { Change }\end{array}$ & F Change & df1 & $\mathrm{d} 2$ & Sig. F Change \\
\hline 1 & $.492^{\mathrm{a}}$ & .242 & .183 & .880 & .242 & 4.097 & 5 & 64 & .003 \\
\hline
\end{tabular}

a. Predictors: (Constant), Aware, Relevance Significance, Cost, Beneficial, Add value.

Source: prepared by authors.

The model summary table shows an R-value of 0.492 , an $\mathrm{R}$ square value of 0.242 and an adjusted $\mathrm{r}$ square value of 0.183 . The $\mathrm{R}$ square value is key for a factor analysis since it quantifies the percentage change independent variable which is caused the independent variables namely relevance and significance of IR, awareness, cost, benefits of $<\mathrm{IR}>$ and the value added. In a study done by Lehmann (1975), it was found that for most researches and studies, the value of R squared lied between $0.10-0.50$ which is in line with the results obtained for this study. It can be concluded that $24.2 \%$ of the variance in the dependent variable adoption of $<\mathrm{IR}>$ can be explained by the independent variables. The same value suggests that $75.8 \%$ of the variance in the dependent variable is explained by other independent variables which have not been considered in this study. The following table is the ANOVA table. This table shows the mean square, the $\mathrm{F}$ value, the significance level and the degree of freedom.

Table 2. ANOVA

\begin{tabular}{|c|c|c|c|c|c|c|}
\hline \multicolumn{2}{|c|}{ Model } & Sum of Squares & df & Mean Square & F & Sig. \\
\hline \multirow{4}{*}{} & Regression & 15.850 & 5 & 3.170 & 4.097 & $.003^{\mathrm{b}}$ \\
\cline { 2 - 8 } & Residual & 49.522 & 64 & .774 & & \\
\cline { 2 - 8 } & Total & 65.371 & 69 & & & \\
\hline
\end{tabular}

a. Dependent Variable: Has your company adopted the $<\mathrm{IR}>$ concept?

b. Predictors: (Constant), Aware, Relevance Significance, Cost, Beneficial, Add value

Source: prepared by authors.

The $\mathrm{F}$ value looks at the overall significance of a multiple regression analysis. In order to check whether the regression analysis is significant, the common practice is that the p-value should be less than 0.05 . Data from the table suggests that the $F$ value is 4.097 while the $p$-value is 0.003 . This implies that the regression analysis is significant and appropriate to determine the relationship between adoption of IR and the independent variables namely: awareness, relevance, cost, benefits of IR, and the value added. In order to be able to generate a regression equation, the coefficients table was checked and the appropriate values were extracted.

Table 3. The relationship between adoption of IR and the independent variables

\begin{tabular}{|c|c|c|c|c|c|c|}
\hline \multirow{2}{*}{\multicolumn{2}{|c|}{ Model }} & \multicolumn{2}{|c|}{ Unstandardized Coefficients } & \multirow{2}{*}{$\begin{array}{c}\begin{array}{c}\text { Standardized } \\
\text { Coefficients }\end{array} \\
\text { Beta } \\
\end{array}$} & \multirow[b]{2}{*}{$\mathrm{t}$} & \multirow[b]{2}{*}{ Sig. } \\
\hline & & $\mathrm{B}$ & Std. Error & & & \\
\hline \multirow[t]{6}{*}{1} & (Constant) & .300 & .492 & & 1.992 & .051 \\
\hline & Relevance \& Significance & .041 & .366 & .018 & .112 & .911 \\
\hline & Add value & .260 & .284 & .142 & .915 & .364 \\
\hline & Cost & -.029 & .098 & -.035 & -.293 & .770 \\
\hline & Beneficial & .383 & .155 & .319 & 2.465 & .016 \\
\hline & Aware & .163 & .112 & .186 & 1.462 & .149 \\
\hline
\end{tabular}

Source: prepared by authors.

\section{Dependent Variable: Has your company adopted the IR concept?}

The coefficient table is the criteria as to whether to accept or reject factors. The significance level of 5\% was set and any p-value less than $5 \%$ were rejected. From the above table, the beneficial factor $(0.016)$ is the only variable which has a p-value between $0 \%$ and $5 \%$ and is therefore rejected. All independent variables except cost factor had a negative relationship with the adoption of IR. The regression equation can be obtained from the coefficients table as follows:

$Y=0.300+0.41 X_{1}+0.260 X_{2}-0.029 X_{3}+0.383 X_{4}+0.163 X_{5}$

Where $Y=$ Dependent variable, $<I R>$ Adoption

$X 1=$ Independent variable, Relevance

$X 2=$ Independent variable, Add value 
$X 3=$ Independent variable, Cost

$X 4=$ Independent variable, Beneficial

$X 5=$ Independent variable, Awareness

From this analysis, it can be highlighted that the factors which influence the adoption of $<\mathrm{IR}>$ are backed by the literature review.

Finally, all survey participants were asked what they see as the three main challenges in adopting. However, only the responses from the knowledgeable respondents ( 3 or above five-point scale) have been analyzed to avoid biasness. Emerging at the top of the list is the fear of divulging market and/ or price sensitive information (56\%). Compared to other surveys conducted where this challenge was not the main one, for the purpose of this research, however, participants have acknowledged that IR would provide more balance reporting to all stakeholders but they have the fear of not being able to balance the information disclosed, especially when it comes to sensitive information. As indicated by du Toit, Van Zyl, Schutte (2017), significant uncertainty will remain regarding the amount of disclosure required, even among South African companies which are the pioneer of IR. The second-ranked perceived challenge is the lack of a proper information system to produce the IR (49\%). Dumay, Bernardi, Guthrie \& Demartini (2017) similarly report inadequate information systems as a barrier to IR implementation. This can be explained by the broad range of information required by stakeholders today, implying that companies need to cover the information in up to date systems so that reliable reports can be generated. It is also important to note that IR is a new concept, therefore, it might take some time to evolve a company's information systems to support the shift to integrated thinking. It cannot happen overnight. The third-ranked challenge perceived by $41 \%$ of the respondents is the cost of preparation. Some respondents clearly doubt whether the benefits of IR would outweigh the costs. They also believe adoption of IR may further increase the cost of doing business. The lack of guidance on how to prepare an integrated report is also a key challenge in the eyes of $36 \%$ of the respondents. This concern comes through strongly in responses to later survey questions asking about the support participants would like when adopting IR, where the use of technological tools and training are common requests.

From previous research, it can be concluded that survey participants were least concerned about the risk ground-level resistance to within organizations. However, in this survey, this concern is quite substantial (identified by $30 \%$ of respondents). This may be because IR is a new concept and it is taking off gradually. Therefore, preparers of IR would have some reluctance if they are not given the appropriate training or ample time to grasp the concept well.

Similarly, the lack of connectivity and integration process within organizations to enable adoption of IR is seen as a substantial challenge (identified by $29 \%$ ). This can be mitigated by having a content guideline for each section of the annual report and an overall reviewer on contents help to overcome this challenge. Lack of support from the board and senior management is a challenge identified by $20 \%$ of respondents. Even if this challenge is not highly substantial, board commitment and the backing are vital for any major initiative within an organization, and IR is no exception. Almost $17 \%$ of respondents see a hurdle arising from fear of litigation given the uncertain outcomes of forward-looking information that might be included in an IR. It should be clarified that the International IR Framework is principle-based and does not prescribe the specific content. Companies need to use their judgment to determine what is considered material information that should be included to give readers a better understanding of their value creation potential.

Survey participants are least concerned about insufficient evidence of investor's interest, which is identified as a challenge by only $7 \%$. This suggests the investors appear to be recognizing that IR is designed to give them a more complete picture of a company's ability to create value over the short, medium and long-term. This can also be backed the high number of positive responses when participants were asked if they believe that if IR is commonly used by companies in Mauritius, they will make the economy more attractive to investors. While many respondents do see value for Mauritian businesses in adopting IR, noting its potential to increase transparency and provide investors with useful information, they also consider it a 'magic bullet' that will automatically attract investors. Tackling these challenges is not necessarily easy or straightforward, but an increasing range of resources is available to corporate reporters and their advisers to help them implement and prepare IR successfully. An important first step to take in order to tackle the challenges discussed above is to achieve board level and company-wide buy-in for IR. This requires discussion and analysis of the relative costs and benefits of IR adoption. The IIRC has produced a series of documents intended to highlight how IR creates value for different groups, such as company boards and investors (IIRC, 
2013). Moreover, if proper training and educational activities are provided for companies to prepare for IR adoption, these challenges could be mitigated. Several previous studies explore perception of IR in different countries from the perspective of different stakeholders. Perego, Kennedy \& Whiteman (2016) suggested that IR is perceived as a diverse field, where progress is being made despite challenges. The findings of this study so far indicate that there has been strong interest in IR in Mauritius, but it is equally important to gather respondents' perception about training, support, and relevant tools and technologies so that companies can effectively implement and make use of this approach.

\section{Conclusion and Recommendation}

The findings exhibit that most of the respondents had the knowledge of IR, although it is a fairly new concept in Mauritius. Further, respondents were asked if their companies have adopted the concept and only a minority mentioned that they are considering to adopt it while the majority have already implemented and they are using it as a new means of reporting. Most importantly, they agreed that IR has several positive outcomes and more stress should be placed on gaining knowledge and skills to prepare the integrated reports. Moreover, to be able to effectively use IR, they found it relevant to have adequate skills to use reporting technologies. Among the 70 companies that participated in the survey, most of them (56\%) have recently adopted IR. Based on the results obtained from the survey conducted, it can be concluded that IR changes the volume and extent of the disclosures. The adoption of IR is bringing many benefits to organizations and stakeholders and the benefits outweigh the few challenges it poses.

Future studies in the context of Mauritius could include a study to identify and to evaluate the ICT topics and techniques which are currently being taught in accounting faculties in Mauritius and whether they are relevant to the IR concept. Also, it could include an evaluation of whether HEIs possess the appropriate conditions to meet the challenges of emerging ICTs in Accounting Education. Moreover, a study to examine the attitude of accounting academics and students towards the use of relevant ICT in the teaching and learning process.

\section{References}

1. $<$ IR $>$ Technology Initiative. (2016). Technology for Integrated Reporting: A CFO guide for driving multi capital thinking. Retrieved from: http://integratedreporting.org/wp-content/uploads/2016/10/Technologyfor-Integrated-Reporting_CFOguide.pdf

2. Adhariani, D., \& de Villiers, C. (2018). Integrated reporting: perspectives of corporate report preparers and other stakeholders. Sustainability Accounting, Management and Policy Journal, SAMPJ-02-20180043. https://doi.org/10.1108/SAMPJ-02-2018-0043

3. Ahmed Haji, A., \& Anifowose, M. (2016). The trend of integrated reporting practice in South Africa: Ceremonial or substantive? Sustainability Accounting, Management and Policy Journal, 7(2), 190-224. doi:http://dx.doi.org.dbgw.lis.curtin.edu.au/10.1108/SAMPJ-11-2015-0106

4. Ahmed Haji, A., \& Anifowose, M. (2017). Initial trends in corporate disclosures following the introduction of integrated reporting practice in south africa.Journal of Intellectual Capital, 18(2), 373399. doi:http://dx.doi.org.dbgw.lis.curtin.edu.au/10.1108/JIC-01-2016-0020

5. Ahmed Haji, A., \& Hossain, D. M. (2016). Exploring the implications of integrated reporting on organisational reporting practice. Qualitative Research in Accounting and Management, 13(4), 415-444. Retrieved from com.dbgw.lis.curtin.edu.au/docview/1829435440?accountid=10382

https://search-proquest-

6. Atkins, J. F., Solomon, A., Norton, S., \& Joseph, N. L. (2015). The emergence of integrated private reporting. Meditari Accountancy Research, 23(1), 28-61. Retrieved from https://search-proquestcom.dbgw.lis.curtin.edu.au/docview/1668188838?accountid=10382

7. Atkins, J., \& Maroun, W. (2015). Integrated reporting in South Africa in 2012.Meditari Accountancy Research, 23(2), 197-221. Retrieved from https://search-proquestcom.dbgw.lis.curtin.edu.au/docview/1692034938?accountid=10382

8. Bhasin, D. (2017). Integrated Reporting at the Crossroads: Will it Become Trendsetter Model for the Corporate Reporting. International Journal of Management Sciences and Business Research, 6(2). Available at: http://www.ijmsbr.com/Volume\%206\%20Issue\%202\%20Paper\%204.pdf

9. Deegan, C., \& Rankin, M. (1997). The materiality of environmental information to users of annual reports. Accounting, Auditing \& Accountability Journal, 10(4), 562-583. https://doi.org/10.1108/09513579710367485.

10. du Toit, E., van Zyl, R. and Schütte, G. (2017). Integrated reporting by South African companies: a case study. Meditari Accountancy Research, 25(4), 654-674. https://doi.org/10.1108/medar-03-2016-0052 
11. Dumay, J., Bernardi, C., Guthrie, J., \& Demartini, P. (2016). Integrated reporting: A structured literature review. Accounting Forum, 40(3), 166-185. https://doi.org/10.1016/j.accfor.2016.06.001

12. Eccles, R. (2010). One Report: Are You Ready? Don't let the skeptics stop you from integrated reporting. IESE Insight, (5), 6-6. https://doi.org/10.15581/002.opi-892

13. Eccles, R. and Saltzman, D. (2011). Achieving sustainability through integrated reporting. Stanford Social Innovation Review, 9(3), 56-61.

14. Etikan, I. (2016). Comparison of Convenience Sampling and Purposive Sampling. American Journal of Theoretical and Applied Statistics, 5(1), 1. https://doi.org/10.11648/j.ajtas.20160501.11

15. EY (2017). Why Richard Howitt is on a mission to improve corporate reporting. Retrieved from https://www.ey.com/en_gl/assurance/why-richard-howitt-is-on-a-mission-to-improve-corporatereporting

16. García-Sánchez, I., Rodríguez-Ariza, L. and Frías-Aceituno, J. (2013). The cultural system and integrated reporting. International Business Review, 22(5), 828-838. https://doi.org/10.1016/j.ibusrev.2013.01.007

17. GRI. (2018). Integrated Reporting. Retrieved from https://www.globalreporting.org/information/currentpriorities/integrated-reporting/Pages/default.aspx

18. Haller, A., \& Chris, v. S. (2014). The value added statement - an appropriate instrument for integrated reporting. Accounting, Auditing \& Accountability Journal, 27(7), 1190-1216. doi:http://dx.doi.org.dbgw.lis.curtin.edu.au/10.1108/AAAJ-04-2013-1307

19. Hopwood, A., Unerman, J., \& Fries, J. (Eds.). (2010). Accounting for sustainability: practical insights. Retrieved from https://ebookcentral.proquest.com

20. Hsiao, P. and Kelly, M. (2018). Investment considerations and impressions of integrated reporting. Sustainability Accounting, Management and Policy Journal,9(1), 2-28. https://doi.org/10.1108/sampj-10-2016-0072

21. IIRC (2013). The international Integrated Reporting framework | Integrated Reporting. Retrieved from http://integratedreporting.org/wp-content/uploads/2015/03/13-12-08-THE-INTERNATIONAL-IR-

FRAMEWORK-2-1.pdf

22. IIRC. (2015). IIRC Integrated Report 2015 | Integrated Reporting. Retrieved from http://integratedreporting.org/news/iirc-integrated-report-2015/

23. ISCA-NUS. (2014). Integrated reporting survey 2014 [EBook]. Institute of Singapore Chartered Accountants (ISCA). Retrieved from https://isca.org.sg/media/775709/isca-nus-integrated-reportingsurvey-2014.pdf

24. Islam, R. and Islam, M.R. (2018). Insights the Practice of Integrated Reporting: A Study on MNCs in Bangladesh on the Degree of Adherence to the Reporting Framework. Open Journal of Business and Management, 6, 733-748. https://doi.org/10.4236/ojbm.2018.63056

25. Lehmann, D. (1975). Validity and Goodness of Fit in Data Analysis. Retrieved from http://acrwebsite.org/volumes/5796/volumes/v02/NA-02

26. Lipunga, A. (2015). Corporate Social Responsibility Reporting through the Lens of ISO 26000: A Case of Malawian Quoted Companies. International Business Research, 8(2). http://dx.doi.org/10.5539/ibr.v8n2p28

27. Lodhia, S. (2015). Exploring the transition to integrated reporting through a practice lens: An australian customer owned bank perspective. Journal of Business Ethics, 129(3), 585-598. doi:http://dx.doi.org.dbgw.lis.curtin.edu.au/10.1007/s10551-014-2194-8

28. McNally, M., Cerbone, D., \& Maroun, W. (2017). Exploring the challenges of preparing an integrated report. Meditari Accountancy Research, 25(4), 481-504. Retrieved from https://search-proquestcom.dbgw.lis.curtin.edu.au/docview/1948367329?accountid=10382

29. MIA-ACCA. (2016). Integrated Reporting Survey [EBook]. Malaysian Institute of Accountants (MIA). Retrieved from http://integratedreporting.org/wp-content/uploads/2016/09/MIA-ACCA-IR-surveyreport_2016.pdf.pdf

30. Nylander, J. (2015). Why 'Integrated Reporting' Attracts Investors [Blog]. Retrieved from https://www.forbes.com/sites/jnylander/2015/11/11/why-integrated-reporting-attractsinvestors/\#26ca523c57e7

31. Owen, G. (2013). Integrated Reporting: A Review of Developments and their Implications for the Accounting Curriculum. Accounting Education, 22(4), 340-356. https://doi.org/10.1080/09639284.2013.817798

32. Perego, P., Kennedy, S., \& Whiteman, G. (2016). A Lot of Icing but Little Cake? Taking Integrated Reporting Forward. SSRN Electronic Journal. https://doi.org/10.2139/ssrn.2744822 
33. Petrova, M. (2015). The Art of Business Strategy. Is Integrated Reporting a continuation of strategy by other means? [Blog]. Retrieved from http://www.kksadvisors.com/blog/2016/9/12/the-art-of-businessstrategy-is-integrated-reportinga-continuation-of-strategy-by-other-means

34. Reimsbach, D., Hahn, R., \& Gürtürk, A. (2017). Integrated Reporting and Assurance of Sustainability Information: An Experimental Study on Professional Investors' Information Processing. European Accounting Review, 27(3), 559-581. https://doi.org/10.1080/09638180.2016.1273787

35. Rensburg, R., \& Botha, E. (2014). Is Integrated Reporting the silver bullet of financial communication? A stakeholder perspective from South Africa. Public Relations Review, 40(2), 144-152. https://doi.org/10.1016/j.pubrev.2013.11.016

36. Robertson, F. A., \& Samy, M. (2015). Factors affecting the diffusion of integrated reporting - a UK FTSE 100 perspective. Sustainability Accounting, Management and Policy Journal, 6(2), 190-223. doi:http://dx.doi.org.dbgw.lis.curtin.edu.au/10.1108/SAMPJ-07-2014-0044

37. Roman, A. (2017). King III Report: How South Africa Revolutionised Corporate Governance. Azeus Convene. Available at: https://www.azeusconvene.com/south-africa-revolutionize-corporate-governance

38. SEM. (2018). Stock Exchange of Mauritius (SEM) - Listed Companies | AFRICAN MARKETS. Retrieved from https://www.african-markets.com/en/stock-markets/sem/listed-companies

39. Setia, N., Abhayawansa, S., Joshi, M., \& Huynh, A. V. (2015). Integrated reporting in South Africa: Some initial evidence. Sustainability Accounting, Management and Policy Journal, 6(3), 397-424. doi:http://dx.doi.org.dbgw.lis.curtin.edu.au/10.1108/SAMPJ-03-2014-0018

40. Steyn, M. (2014). Organisational benefits and implementation challenges of mandatory integrated reporting. Sustainability Accounting, Management and Policy Journal, 5(4), 476-503. Retrieved from https://search-proquest-com.dbgw.lis.curtin.edu.au/docview/1633971308?accountid=10382 